\title{
Integration of Technology Management and its Development TECHNOLOGY IMPLEMENTATION AND COMMERCIALIZATION
}

\author{
Marek Jemala*
}

\section{Introduction}

Integrated technology management should enable a company to better evaluate, plan, carry out, link, and control technological processes and elements so that they are mutually supportive and synergistic. However, integration of TM processes does not only mean technology integration activities. These activities are mainly targeted at analyzing, evaluating and developing a better technological system (Iansiti, 1997). Integration of TM processes also requires the integration of various departments and levels of management (Madhani, 2011), integration of a business strategy and an infrastructure (Gunasekaran and Ngai, 2004), integration of varying stakeholders, keeping pace with technological progress, etc. Integrating technology capacities with customers' needs, technology with business strategy, technology and other business processes, and technology elements and processes often require a three-step mechanism of TM, namely integration of technology identification, implementation, and potential technology commercialization processes. All these processes should be properly connected and implemented systemically.

Systematic technology innovation must be integrated with effective businessrelated changes in and outside a company (e.g., adjustment of related jobs, new performance and quality standards, adjustment of supply, storage and sale capacities, marketing and PR, modification of calculations and budgets, etc.). These activities should be a part of systemic planning and implementation processes within integrated TM (Leonardi, 2008). These processes can be supported by different stakeholders, e.g., technological suppliers that can be a significant "source" of information and inventions, outsourcing companies that can be technology integrators as well, etc. Currently, the integration of technological systems from a variety of vendors or developers can be seen as the main issue in the ICT industry (Peslak, 2011). Many larger companies have therefore established special formations for the preparation of technology implementation processes.

For example, IBM has developed the IBM Interactive Team, which is designed to spread the vision, mission, business strategy, acquired technology innovation, new management or marketing expertise through the worldwide network of IBM centres. New technological know-how is initially approved by an internal technology assessment

\footnotetext{
* School of Engineering and Management, University of Nova Gorica, Slovenia (marek.jemala@ung.si).
} 
process and subsequently distributed to other IBM centres. These centres offer a unique „think tank“, in which experts collaborate with users, and thus better evaluate, plan, develop, link and start new technological projects. The IBM interactive team enables performance of user-oriented technology analyses and surveys (industrial or end users) and on-line technology integration and implementation (IBM, 2010).

This article builds on the preceding article named Integration of technology management and its development - Interlevel overlap and technology identification, and is mainly focused on identifying integrative aspects in technology management, mainly in its technology implementation and commercialization phases that are highly important for the profitability of TM.

\section{Integration within technology implementation processes}

Technology implementation requires a technological change/innovation which calls for an adequate adaptation mechanism that should allow tracking new technology in a company, including technology development needs, change in organizational culture, and setting new personnel tasks (Kamath et al., 2011). Technology implementation requires the support of top management (especially at the beginning), who should provide visionary leadership and clearly articulate technology needs across the company (Trainor et al., 2010). Technological implementation may also include the management of an existing technology portfolio. Technology portfolio management can enable optimizing interdependent technology projects over multiple time periods and conditions (Dickinson et al., 2001). It is necessary to systematically monitor links among business technological applications, and also to ensure their safe disintegration ${ }^{1}$.

Through the technological implementation phase, it is appropriate to integrate individual processes of technological $\mathrm{R} \& \mathrm{D}$ and practical innovation, innovation requirements and technological education programmes, and technology portfolio management with business needs. Technology innovation and changes as outputs of internal R\&D activities are usually highly conditioned by marketing analyses and management requirements. Technology innovation can also be conditioned by suppliers, who may be a very valuable source of inventions. However, technology innovation can also be an outcome of technology transfer or an outsourcing process. For any type of gathering of improved or new technology, there is always a need to adequately plan and integrate these processes in terms of required resources, capacities, networks, timeframe, relation to existing business processes, and expected outcomes. However, there is also a need to identify trends and risks that may accompany innovation processes. The most appropriate visual instrument in this context can be a roadmapping plan designed to integrate resources, capacities, technologies, products, markets or customers in order to achieve strategic business objectives. This integration should also take place at every level of the plan, in terms of time series of individual elements of the plan. A roadmapping plan displays several variant technological scenarios for possible different states of the environment (Figure 1).

1 This makes it possible to change a technology system or its parts if conditions change. 
A company can link radical and incremental technology innovation, systematic and random innovation, and process or product-oriented technology innovation. ${ }^{2}$ Processes of incremental innovation can create conditions for radical improvements. To keep improving radical innovation, this requires continuing with follow-up incremental technology innovation. Radical innovation, however, can sometimes only be subject to a significant increase in investment. ${ }^{3}$ Then, it is necessary to adequately integrate capital resources, personnel capacities, and conditions suitable for the innovation. Process-oriented technological innovation is aimed at improving an existing or creating a better technology system. This innovation requires more systemic organizational changes and higher technology costs. Product-oriented technological innovation is aimed at a new or improved use or handling of products of a company. This innovation requires more periodic technical changes in order to be more marketacceptable. However, any innovation should be appropriately planned and integrated in order to be feasible.

\section{Figure 1}

\section{Technology innovation integration using a roadmapping plan}

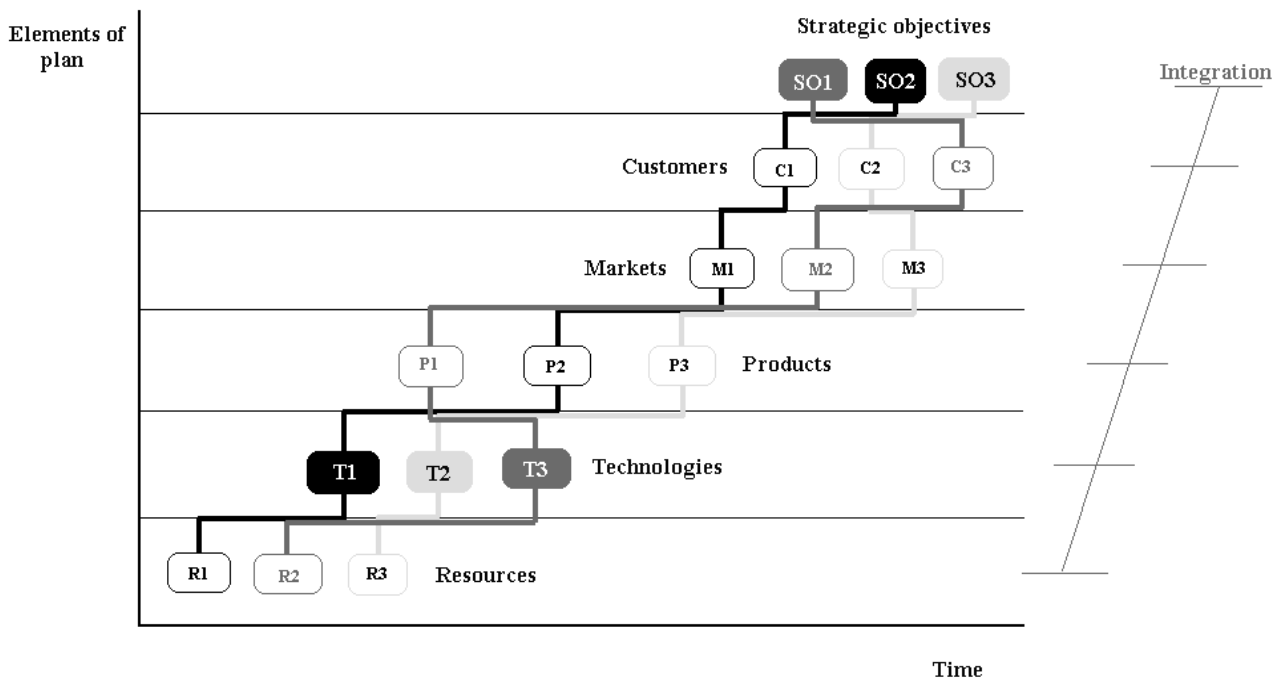

Source: Own scheme

2 Incremental technology innovation is usually more systematic improvement of technological processes at repeated intervals. Such innovation is usually associated with partial new technological findings and knowledge. Radical technology innovation is a process where a completely new discovery can change procedures and principles of existing technology. These changes are often incidental findings and their cardinal effect often means significant changes to a company or an industry.

3 Technology innovation can be conditioned by new discoveries, new market demands or capital-conditioned changes, etc. 
We can also distinguish between technological innovation which does not bring product innovation (e.g., saving energy, time, cost), and product-technology and servicetechnology innovation. An indirect effect of product innovation through improved economic results can bring better opportunities for organizational changes. In general, technological innovation and changes are often more expensive, laborious and risky, although their marketing costs are usually below the product innovation costs. Figure 2 shows a model technology integration structure within particular innovation activities. ${ }^{4}$

Cooperative innovation can enable a company to take advantage of resources, capacities, or know-how of different institutions (Chen and Kang, 2011). An open innovation strategy (OIS) should be a part of a business strategy, but usually it exceeds the commercialization of technology (Fosfuri, 2006). An OIS presupposes an integrated use of R\&D and related capacities among firms, laboratories or universities (also internationally). For example, Haier was the first company in China that extended its open technology innovation strategy overseas. In May 2000, Haier's refrigeration division allied with US Dow and Motorola, and Brazilian Embraco to form the global technology innovation union. Through the numerous business integration processes, the joint technological applications have been constantly upgraded so that the companies can obtain a better competitive advantage and economic results. This open innovation cooperation enables Haier to achieve an international advanced level in digital, intelligent and frequency-conversion technology standards ${ }^{5}$ (Chen and Kang, 2011).

4 Many of these activities may be carried out simultaneously or in a different order depending on particular company's requirements.

5 Haier is the leading producer of white goods and the most valuable brand in China. The company is divided into 29 manufacturing plants, 8 comprehensive R\&D centers, 16 industrial parks, 19 overseas trading companies, and has more than 60000 global employees. In 2008, the company achieved the global revenue of around 13 billion EUR (Haier, 2011). The company still holds "borrow strengths” of innovation ideas. Moreover, in the last decade, the company has been cooperating with more than 100 domestic research institutions, universities and other overseas companies on developing new technology solutions (Chen and Kang, 2011). 


\section{Figure 2}

Primary technology integration within particular innovation activities

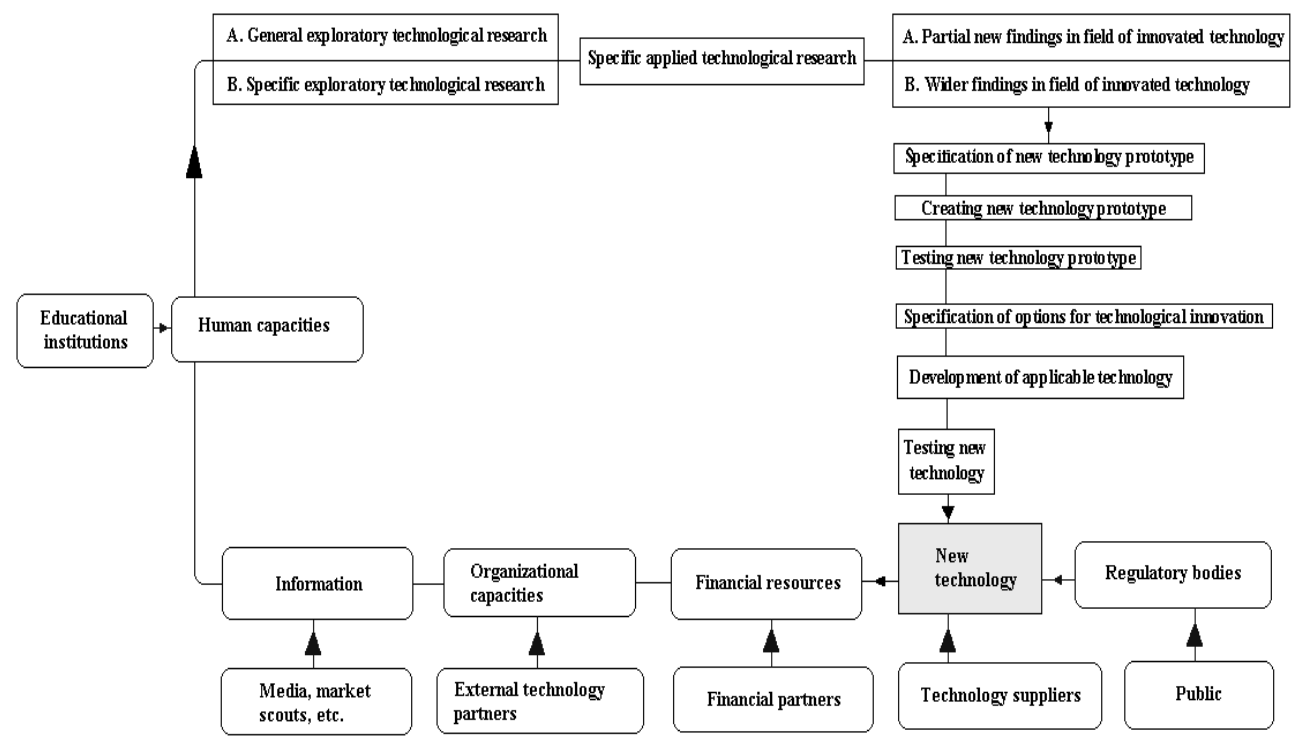

Source: Own scheme

An OIS, however, requires more demanding integration processes which should be based on adequate cooperation contracts that can enable a company to obtain better R\&D scale advantages. For example, coupling of renewable energy companies (e.g., wind, solar or geothermal) with companies dealing with desalination technology holds a great promise for water scarcity issues ${ }^{6}$ (Dehmas et al., 2011). However, the main risk is in sharing relevant technological and business know-how. It is therefore necessary to adequately protect key technological expertise, and then to decide which business details may be disclosed, when, and which capacities can be integrated. Thus, the OIS can be limited by the level of restrictions given by TM on transferring its technology (Lichtenthaler, 2009). Governments should play an important regulatory role in this process through appropriate laws and favourable policies, as well as a supporting role through governmental guarantees and loans.

Many companies are not necessarily open to transferring their technology and rather create a strategic alliance. Vestas and Boeing created an alliance for the cooperation in joint innovation projects with environmentally progressive types of technology. Vestas develops wind turbines using an in-house research approach, but also cooperates

6 Effective integration of these technological applications can allow countries to better address water shortage problems, and to overcome the problems of rising fuel prices and decreasing fossil fuel supplies (Dehmas et al., 2011). 
with leading universities and research teams worldwide. ${ }^{7}$ Through the Boeing Research $\&$ Technology organizations around the world, Boeing carries out its own R\&D, but also works with leading R\&D institutions, companies and universities. ${ }^{8}$ Boeing and Vestas achieve high quality of their R\&D activities in related areas (such as aerodynamics and material science). The main advantage of this strategic technological integration is a strong correlation between new technology required in the aerospace industry (Boeing) and new technology required in the wind energy sector (Vestas) (Kanter, 2009). Such inter-industrial integration is also one of the main technology trends.

Others include dynamic technology capabilities (DTC), which can enable a company to build and integrate internal and external business capabilities so as to adapt the company to the changing environment. Usually, the function of DTC is knowledge integration and transformation in accordance with external and internal needs which can affect technology integration (Chang and Tzeng, 2010). Knowledge integration is usually a precondition of technology integration. An adequate adaptation of personnel capacities should create a significant part of each innovation strategy (either open or internal). However, technological training and education must be an essential part of integrated TM in each phase, because of the general need for increasingly flexible personnel and especially R\&D capacities. Such capacities can allow starting an innovation project quickly if there is a good opportunity.

A dual-ladder system of education has become a necessity in many manufacturing industries. ${ }^{9}$ Self-organised skills and creativity are required at all levels, albeit in varying forms. Technical education makes up a part of Management and Economy subjects at many universities. ${ }^{10}$ However, there is evidence that technical and managerial education (in general) is still not connected properly, not only at universities but also in companies. This fact can be a significant obstacle to better integration of TM processes and better innovation results (Barella and Buffinton, 2009). Currently, an important role in technology innovation processes belongs to universities that concentrate and generate a large amount of technological know-how, but they must create specific vital links between business R\&D, public R\&D laboratories and markets. However, there are several integration issues that call for a well-balanced approach within TM integration. Initially, there is usually an unequal technical/engineering and managerial path (Cegarra et al., 2010). The managerial path is usually based on the technical/ engineering path, but the other way is rarely found. Secondly, researchers' career paths have become more varied than it allows for. Companies have usually required researchers with the best technical competence, but only average managerial skills. Therefore, appropriate integration and well-balanced technical and managerial expertise are an essential precondition for better TM results.

7 Danish Vestas is the world's largest producer of wind turbines and wind energy.

8 U.S. Boeing is the largest manufacturer of commercial and military aircrafts.

9 A dual-ladder system or a double pillar system in TM means connecting technical knowledge and managerial/economic skills of technological employees to achieve better business results.

10 For example, Stanford University and Massachusetts Institute of Technology have included Engineering in their management subjects. Harvard and Cambridge universities also integrate technical programs into their management education (Bellamy et al., 2001). 
If we look at the development of technology implementation processes using bibliometric statistics, then it is clear that technology education and technology innovation are the most developed processes. From the time perspective, technology education has again been the most developed process since approximately the $1960 \mathrm{~s} .{ }^{11}$ In terms of time, technology educational processes belong among the most developed of all the TM processes. This may indicate a very important role of technology education in TM in the long term. In terms of the development of particular integration aspects within technology implementation, technology innovation processes registered the most hits. From the time perspective, the initial integration aspects in technological implementation can be found in the 1990s, at the time of the Internet invention or the new rise of Microsoft (Chart 1, Table 1).

\section{Chart 1}

\section{Development of technology implementation processes - Cumulative number of professional articles ${ }^{12}$}

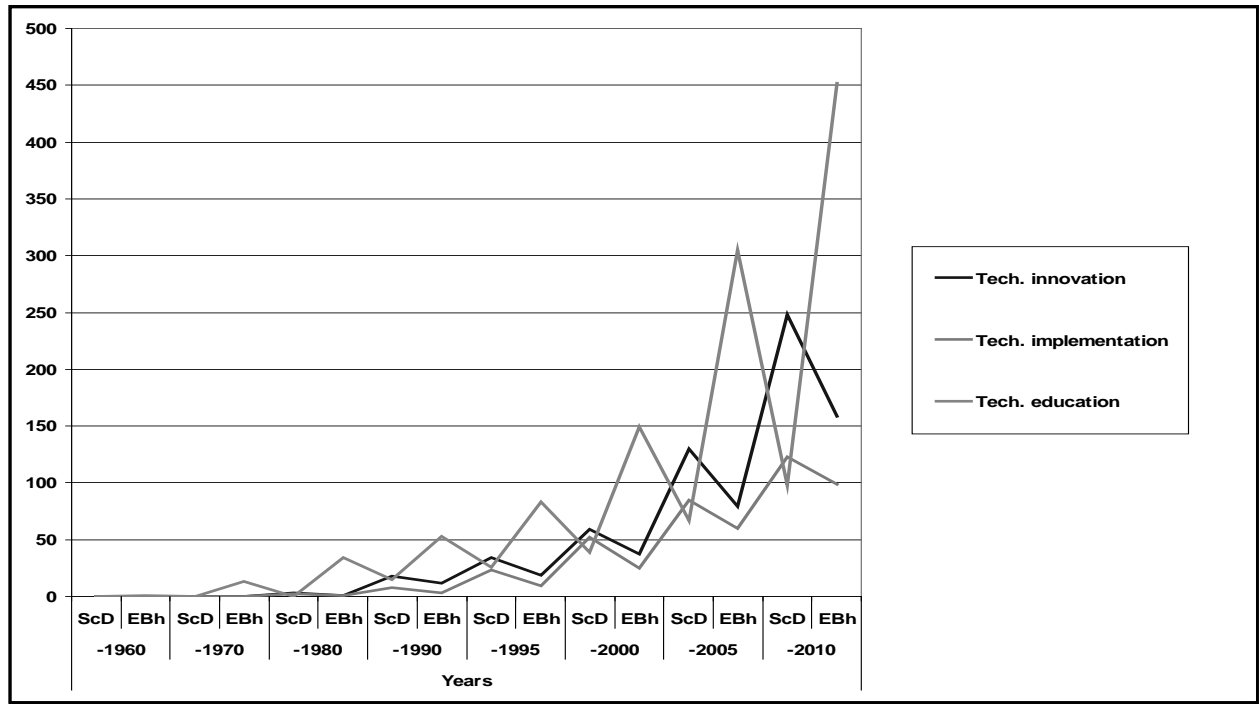

Source: Sciencedirect, 2011; EBSCOhost, 2011

11 One of the first books to deal with technology education aspects was named "Soviet Education for Science and Technology" and published by Cambridge University Press in 1957. The book with an encyclopedic character (513 p.) described the Soviet educational system especially focused on mathematics and physics (Korol, 1957).

12 Graph 1 and Table 1 were compiled based on the Bibliometrical statistics. The listed numbers refer to the number of professional articles published in titles, abstracts, and key words of refereed journals and books registered in the Sciencedirect database $(\mathrm{ScD})$ and in scholarly (peer reviewed) journals of the EBSCOhost database (Ebh). 


\section{Integration within technology commercialization processes}

Capacity limitations and risk constraints require an organization to systemically allocate its resources and investment to a subset of possible technology projects. It is necessary not only to make technological capacities more flexible and to adequately integrate them, but also to use appropriate instruments in order to prepare and carry out optimal technology projects.

\section{Table 1}

Development of technology implementation integration processes - Cumulative number of professional articles

\begin{tabular}{|c|c|c|c|c|c|c|c|c|c|c|c|c|c|c|c|c|}
\hline & \multicolumn{16}{|c|}{ Years } \\
\hline & \multicolumn{2}{|c|}{-1960} & \multicolumn{2}{|c|}{-1970} & \multicolumn{2}{|c|}{-1980} & \multicolumn{2}{|c|}{-1990} & \multicolumn{2}{|c|}{-1995} & \multicolumn{2}{|c|}{-2000} & \multicolumn{2}{|c|}{-2005} & \multicolumn{2}{|c|}{-2010} \\
\hline & $\operatorname{ScD}$ & EBh & $\operatorname{ScD}$ & EBh & ScD & EBh & ScD & EBh & $\operatorname{ScD}$ & EBh & ScD & EBh & $S c D$ & EBh & $S c D$ & EBh \\
\hline TECH. ANALYSIS & - & - & - & - & 1 & 1 & 7 & 2 & 14 & 6 & 27 & 9 & 39 & 13 & 60 & 20 \\
\hline $\begin{array}{l}\text { Tech. analysis + } \\
\text { integration }\end{array}$ & - & - & - & - & - & - & 1 & - & 3 & - & 8 & - & 17 & - & 29 & 2 \\
\hline Tech. analysis + strategy & - & - & - & - & - & - & 1 & - & 2 & 1 & 8 & 1 & 16 & 1 & 27 & 2 \\
\hline TECH. ASSESSMENT & - & 1 & 1 & 2 & 99 & 60 & 297 & 386 & 440 & 730 & 597 & 1064 & 749 & 1453 & 1105 & 1934 \\
\hline $\begin{array}{l}\text { Tech. assessment + } \\
\text { integration }\end{array}$ & - & - & - & 2 & 23 & 3 & 52 & 4 & 82 & 5 & 112 & 20 & 158 & 48 & 227 & 90 \\
\hline $\begin{array}{l}\text { Tech. assessment + } \\
\text { strategy }\end{array}$ & - & 1 & 1 & 2 & 31 & 16 & 124 & 86 & 191 & 160 & 261 & 256 & 355 & 501 & 546 & 913 \\
\hline TECH. FORESIGHT & - & - & - & - & - & - & - & - & 4 & 4 & 20 & 10 & 30 & 21 & 51 & 27 \\
\hline TF + integration & - & - & - & - & - & - & - & - & 2 & - & 9 & - & 15 & - & 27 & - \\
\hline TF + strategy & - & - & - & - & - & - & - & - & 2 & 5 & 14 & 6 & 23 & 8 & 41 & 15 \\
\hline TECH. PLANNING & - & - & 1 & - & 5 & 1 & 16 & 7 & 29 & 18 & 37 & 31 & 51 & 46 & 63 & 62 \\
\hline $\begin{array}{l}\text { Tech. planning + } \\
\text { integration }\end{array}$ & - & - & 1 & - & 3 & - & 8 & - & 13 & - & 17 & 1 & 25 & 2 & 34 & 4 \\
\hline Tech. strategy + strategy & - & - & - & - & - & - & 17 & - & 40 & - & 68 & - & 96 & - & 120 & - \\
\hline TECH. RESEARCH & - & - & 2 & 1 & 12 & 3 & 65 & 14 & 129 & 24 & 189 & 40 & 260 & 69 & 340 & 123 \\
\hline $\begin{array}{l}\text { Tech. research + } \\
\text { integration }\end{array}$ & - & - & - & - & - & - & 12 & 1 & 30 & 1 & 38 & 1 & 68 & 2 & 104 & 2 \\
\hline Tech. research + strategy & - & - & - & - & - & - & 10 & - & 25 & - & 37 & - & 72 & 3 & 114 & 3 \\
\hline TECH. DEVELOPMENT & - & - & - & - & 18 & 8 & 146 & 31 & 297 & 59 & 557 & 120 & 856 & 262 & 1280 & 446 \\
\hline $\begin{array}{l}\text { Tech. development + } \\
\text { integration }\end{array}$ & - & - & - & - & 5 & - & 50 & 1 & 111 & 2 & 208 & 4 & 336 & 5 & 492 & 7 \\
\hline $\begin{array}{l}\text { Tech. development + } \\
\text { strategy }\end{array}$ & - & - & - & - & 4 & - & 9 & 4 & 20 & 7 & 46 & 13 & 80 & 26 & 128 & 37 \\
\hline
\end{tabular}

Source: Sciencedirect, 2011; EBSCOhost, 2011 
Technology portfolio management (TPM) should include systematic monitoring, analysis and modification of business technology so that these bring adequate economic results for a company. TPM should start with technology identification and make it possible to evaluate investment scenarios before technology innovation. Where technology projects are interdependent, the difficulty of integration/disintegration with even a moderate number of projects over a small number of key objectives and constraints can have a significant effect on commercialization results (Dickinson et al., 2001). However, there is a wide spectrum of managerial instruments with varying metrics and selection methods to facilitate technology integration and investment allocation. These metrics used in selecting projects vary from quantitative (e.g., ROI, value added, profit) to qualitative measures (e.g., alignment with a business strategy, sustainable development, environmental safety, etc.). If using a mixture of qualitative and quantitative instruments, it can make defining an optimal technology portfolio more complex, but it can lead to information overload and time delays as well. Consequently, managers often select their technology portfolio using an integrated mixture of expert, visualisation and scoring methods and techniques. ${ }^{13}$

In history, Boeing could no longer afford developing and introducing large new airplanes. The management abolished the 747 development program and chartered a new integration team. The company started to look for new solutions to develop a new airplane at half the time and cost. The established ACPS team ${ }^{14}$ had to optimize the portfolio of technology projects to improve the overall product development process. Optimizing product development improvement portfolios was more complex than optimizing $\mathrm{R} \& \mathrm{D}$ portfolios, because product development improvements were interdependent (the success of project A depended on the success of projects B, C, etc.). The complexity introduced by the project interdependency required new integrated decision support instruments to assist in the portfolio balancing process. Funding for the new project was only possible in one of many funding cycles. Finally, the ACPS team had to adapt its activities to the financial plan and used the combination of classical and mapping instruments to successfully manage its technology portfolio. However, these instruments were difficult and time-consuming to apply (Dickinson et al., 2001).

In general, each technology system should integrate so-called core technology (i.e., key production technology and IT, logistics, storage, or handling technology), but also complementary technology (security, controlling, evidence-based, planning technology, etc.). In terms of core technology, there is a trend to develop universal technological platforms that can be used for multiple product lines. In terms of complementary technology, there is a trend to develop solutions that can be modified and amended as they are applied to various conditions. This can significantly facilitate

13 Mathematical, statistical and scoring methods are usually used in TPM when quantitative data are available. Graphics and charting are used to evaluate and visualise qualitative metrics. Expert/heuristic methods are usually used to quantify qualitative metrics (Dickinson et al., 2001).

14 This team came to be known as the Airplane Creation Process Strategy team (ACPS). To manage the ACPS program, a gate review process and a portfolio management process were developed. 
TM processes and reduce associated costs as well negative effects of new technology implementation.

For example, the Electric Power Research Institute (EPRI) published a study indicative of the fact that effective $R \& D$ and subsequent implementation of an integrated portfolio of electricity saving technology in the US could have reduced the costs of $\mathrm{CO}_{2}$ emissions by more than 50\% (EPRI, 2007). For another example, Honeywell provides technology portfolio management as a product that allows companies to integrate and automate their technological processes, controlling technological reliability, safety and effectiveness, as well as determining cost-effective measures for further upgrades of their technology. The company offers products such as Total Plant Solution Honeywell and Experion Process Knowledge System, which are specialized platforms for integrated management of production technology (CCR, 2007).

Technology commercialization should also include an optimal technology protection and marketing mechanism. Technological intellectual property (TIP) protection requires systemic monitoring of technology and IP trends, appropriate management and marketing of technological innovation, its secure transfer so as to avoid erosion of technological knowledge and the associated competitive advantage (Omiti, 2011). TIP protection should begin with an internal business and innovation analysis, and consequently with an analysis of existing legal protection on the market related to the technological innovation. This can help determine what exactly should be protected, in which areas, how and why. To some extent, a company can advertise its technology already during promising $R \& D$ or before obtaining protection for its IP (e.g., through publication of technology purposes). There are multiple possibilities of protecting IP rights associated with technology.

The most common patent protection is usually very time-consuming and expensive. In addition, there are different conditions for issuing a patent in different regions. Patent rights are limited geographically. Another option, copyright, is a set of exclusive rights granted by an author or a creator of a technology solution, including the right to copy, distribute and modify the solution. Copyright is especially required if there is a new technology solution that cannot be patented as usual, e.g., SW. These rights can be licensed, and a licence can be exclusive or transferable to another company. In most jurisdictions, copyright arises upon fixation and does not need to be registered. Trademark is a distinctive sign or a specific symbol that can be used by a company or other legal entity to facilitate identification of products/technologies/services to consumers. Trademark is typically a name, word, phrase, logo, symbol, design, image, or a combination of these elements. The registration of trademarks is again not legally required. Industrial design is a right of an acquirer that protects a unique visual configuration, i.e., a shape, arrangement, composition, colour, or a combination of patterns and colours in two- or three-dimensional forms containing a specific aesthetic value. Registered and unregistered designs are possible based on the need to protect industrial designs in the long term up to 25 years) or only temporarily (up to 3 years). A trade secret may be a formula, procedure, process, design, tool design, or a summary of information that is not generally known or readily identifiable (Slater, 2010). In an incremental component industry like IT - where innovation usually 
builds upon existing technology and small step-by-step improvements rather than radical innovation - inventions are usually highly complex and often require protection by multiple IP rights (Ballardini, 2009).

Therefore, to protect new commercialized technology, it can be necessary to integrate multiple forms of IP rights. For example, a company can sell a patented product technology. This product technology can have a unique visual configuration protected by a design right. The technology may have a business trademark. Additionally, the manual sold with this technology may be protected by a copyright. Thus, the protection of TIP can be a very professionally, legislatively, financially and timeconsuming process. Many times a company has to take the help of an external specialist company or an alliance to develop, change, protect and transfer its technology. Therefore, these processes should be very well planned. It can also be necessary to develop appropriate processes and instruments for safe technological cooperation so that there is no leakage of key technological know-how.

For example, Absolute Robotics was set up in 2007 to develop a technology that would make it possible to upgrade standard industrial robots for advanced manufacturing and aerospace applications. ${ }^{15}$ Absolute Robotics developed a technology that allowed measuring dynamic changes in technological activity (in aerospace) in real time and with a great accuracy. From the beginning of the research, and for the sake of the success of the technology commercialization, the company decided for the initial strategic step to cooperate on the TIP protection and contacted Coller IP Management (CIPM). ${ }^{16}$ CIPM successfully prepared and later applied for the required patent applications on behalf of Absolute Robotics, and also helped the company evaluate the research results in a more systemic way (Coller IP, 2011).

Once a technology has been approved for commercialization, TM should also cooperate with marketing to persuade the public to accept the new technology and to find suitable customers. There must be an affirmative role of business management to help the public better accept the new technology. It is also necessary to overcome risk perception factors (novelty, uncertainty, unfamiliar risks, etc.) of the technology by effective persuasion instruments (i.e., an evidence of higher benefits exceeding problems, etc.). This persuasion requires selecting a form of communication based on the potential customers' character. In addition, there needs to be an active feedback from customers into a regulatory review process (Johnson, 2009).

Technology transfer and sale have become a new business in many industries and should have an integrated status in diversified business strategies as do other

15 The aircraft industry has found it difficult to apply robots in the construction process or advanced manufacturing due to their inadequate accuracy, networking, large volume in-line manufacturing and inspection, because of the distortion and expansion of their joints owing to temperature and stiffness effects. (Demopoulos, 2009).

16 Coller IP Management helps organizations protect and manage their technological IP. It combines patent and trademark attorneys' and commercial expertise to deliver IP management, evaluation and investment services to protect technological assets (Coller IP, 2011). 
relevant business activities. ${ }^{17}$ There are multiple national institutions that support private technology transfer companies, especially as it comes to getting patent or other legal protection. They also provide assistance in marketing and finding a suitable contractual partner, as well as necessary legal services when signing a contract. ${ }^{18}$ Technology transfer and sale often complete one cycle of TM, although many TM processes must be carried out continuously and in parallel. From the beginning of TM integration, it is always necessary to define technological objectives in business strategy and transforming them into technology strategy and technology portfolio plans. Along with $\mathrm{R} \& \mathrm{D}$ of new technology, it is useful to develop processes of adequate IP protection, marketing and sale.

In terms of the technology commercialization development according to bibliometric statistics, it is obvious that technology transfer is the most important process, followed by technological IP protection. From the time perspective, technology transfer has again been the most developed process since approximately the 1960s. Technology marketing is the least developed process; it appeared with the increased importance of intangible assets in society, as well as after the Internet invention in the 1980s. Technology portfolio management is also less developed, on the scene since approximately the 1990s. At that time, companies extended the applications of classical portfolio management intonew productselection and R\&Dresourceallocation issues (Dickinson et al., 2001). In terms of the development of particular integration aspects within the technology commercialization phase, technology transfer registered the most hits, even over time. The earliest integration aspects in technology transfer can be seen in the 1960s. ${ }^{19}$ The transfers at that time were also aimed at preventing an influx of foreign goods and strengthening national positions in the impending international commercial war (Ozaki, 1979) (Chart 2, Table 2).

17 Technology transfer is a process of transferring technological innovation in several ways, not only between $\mathrm{R} \& \mathrm{D}$ and a company, but also within individual sectors or between different sectors. This transfer can be realized between two subjects, but also among several private and public subjects in the same or different industry. The main benefit for a provider of technology is commercialization of its technology and profit from renting or selling the technology. The main benefit for a company that will take over this new technology solution is in reducing costs necessary for R\&D. Among public benefits, it is a new customers' option to buy better and more easily available products. A national economy can receive better tax revenues by improving business sector results and consequently by overall synergistic effects of business development.

18 Thus a government to some extent can promote technology innovation and business development in a country.

19 One of the first articles dealing with technology transfer aspects was named "Improving the Transfer of Government-Sponsored Technology" and was published in Business Horizons in 1966. The article describes the method for improving the transfer of government-sponsored technology in the US and the responsibility of the government for disseminating results of its technology-sponsored research (Steiner, 1966). 


\section{Chart 2}

\section{Development of technology commercialization processes - Cumulative number of professional articles}

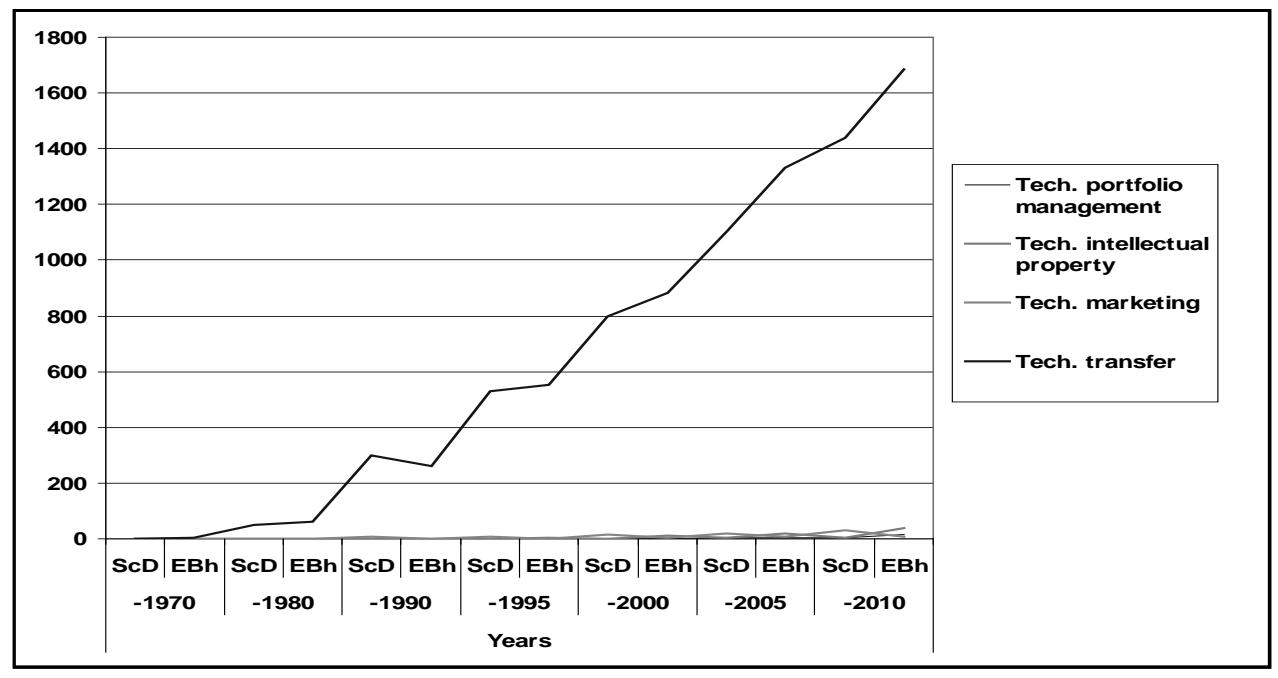

\section{Table 2}

Development of technology commercialization integration processes - Cumulative number of professional articles

\begin{tabular}{|c|c|c|c|c|c|c|c|c|c|c|c|c|c|c|c|c|}
\hline & \multicolumn{16}{|c|}{ Years } \\
\hline & \multicolumn{2}{|c|}{-1960} & \multicolumn{2}{|c|}{-1970} & \multicolumn{2}{|c|}{-1980} & \multicolumn{2}{|c|}{-1990} & \multicolumn{2}{|c|}{-1995} & \multicolumn{2}{|c|}{-2000} & \multicolumn{2}{|c|}{-2005} & \multicolumn{2}{|c|}{-2010} \\
\hline & $\operatorname{ScD}$ & EBh & ScD & EBh & ScD & EBh & ScD & EBh & $S c D$ & EBh & $S c D$ & EBh & ScD & EBh & ScD & EBh \\
\hline $\begin{array}{l}\text { Tech. portfolio } \\
\text { management }\end{array}$ & - & - & - & - & - & - & 1 & - & 1 & - & 1 & 1 & 2 & 5 & 2 & 14 \\
\hline $\begin{array}{l}\text { Tech. portfolio } \\
\text { management }+ \\
\text { integration }\end{array}$ & - & - & - & - & - & - & - & - & - & - & - & - & 1 & - & 1 & - \\
\hline $\begin{array}{l}\text { Tech. portfolio } \\
\text { management + } \\
\text { strategy }\end{array}$ & - & - & - & - & - & - & 1 & - & 1 & - & 1 & - & 2 & - & 2 & - \\
\hline $\begin{array}{l}\text { Tech. intellectual } \\
\text { property }\end{array}$ & - & - & - & - & - & - & - & 1 & - & 3 & - & 11 & 4 & 20 & 5 & 38 \\
\hline $\begin{array}{l}\text { Tech. intellectual } \\
\text { property } \\
+ \text { integration }\end{array}$ & - & - & - & - & - & - & - & - & - & - & - & - & 2 & - & 2 & - \\
\hline $\begin{array}{l}\text { Tech. intellectual } \\
\text { property + } \\
\text { strategy }\end{array}$ & - & - & - & - & - & - & - & - & - & - & - & - & 2 & - & 2 & - \\
\hline Tech. marketing & - & - & - & - & 1 & - & 6 & - & 9 & 1 & 17 & 3 & 21 & 6 & 31 & 8 \\
\hline
\end{tabular}




\begin{tabular}{|c|c|c|c|c|c|c|c|c|c|c|c|c|c|c|c|c|}
\hline $\begin{array}{l}\text { Tech. marketing + } \\
\text { integration }\end{array}$ & - & - & - & - & - & - & 2 & - & 3 & 1 & 5 & 1 & 7 & 2 & 11 & 4 \\
\hline $\begin{array}{l}\text { Tech. marketing + } \\
\text { strategy }\end{array}$ & - & - & - & - & - & - & 3 & - & 5 & 4 & 9 & 8 & 13 & 19 & 21 & 29 \\
\hline Tech. transfer & - & 1 & - & 3 & 49 & 61 & 298 & 260 & 529 & 554 & 800 & 884 & 1102 & 1332 & 1439 & 1683 \\
\hline $\begin{array}{l}\text { Tech. transfer+ } \\
\text { integration }\end{array}$ & - & - & - & - & 13 & 5 & 69 & 12 & 140 & 24 & 230 & 51 & 331 & 116 & 456 & 215 \\
\hline $\begin{array}{l}\text { Tech. transfer+ } \\
\text { strategy }\end{array}$ & - & 1 & - & 4 & 21 & 19 & 133 & 62 & 274 & 106 & 434 & 195 & 623 & 406 & 859 & 734 \\
\hline
\end{tabular}

Both sources: Sciencedirect, 2011; EBSCOhost, 2011

\section{Conclusions}

Integration of technology identification, implementation and potential technology commercialization processes should be an essential part of TM. These processes must be carried out systematically and, if possible, in parallel. Technology identification usually requires adequate external and internal analysis; possibly the creation of a technology radar, subsequent broader technology assessment, foresight/planning and R\&D. Technology implementation requires an adequate business adaptation mechanism, including personnel training and development. Technology portfolio management is another part of technology implementation, related to technological capacities and resources allocation. Subsequent commercialization of technology has become a new line of business in many industries. This commercialization is usually accompanied by acquisition of adequate IP protection associated with the technology, appropriate marketing and a follow-up technology transfer or sale. From the beginning of TM integration, it is always necessary to define technological objectives in business strategy and transform them into a technology strategy and plans. Along with R\&D of a new technology, it is useful to develop processes of adequate IP protection, marketing and sale.

If we look at the development of technological implementation processes through bibliometric statistics, it is clear that technological education and technology innovation are the most significant processes. Technology assessment, education, and transfer dominates in terms of the TM history, namely since the 1960s. In the 1960s, we can find the earliest integration aspects in TM, in which the processes of technology transfer and assessment were integrated with business strategies. The 1960s are described by historians as the decade having the most significant impact in our history. ${ }^{20}$ The most significant process within technology commercialization is technology transfer, followed by the protection of technological IP and portfolio management. Technological portfolio management (TPM) is the least developed process in terms of this analysis as well as in terms of time, i.e., since the 1990s. Risk society is a term that emerged in the 1990s because of the increasing environmental concerns that required

20 By the end of the decade humanity had entered the space-age and there was increasing interest in new technology. 
new portfolio approaches. The earliest integration aspects in TPM can be found around 2005. At that time, the dynamics on the technology portfolio market were leading to more complex and costly technological solutions. Users required better prioritizing application development while controlling application portfolio demand, and vendors had to increasingly apply new marketing-integrated solutions (Gartner, 2005). As is obvious, these requirements are still the trend.

From the general perspective of all the three TM phases, technology identification dominates as the most challenging phase of TM, followed by technology implementation. The least developed phase is technology commercialization as a relatively new form of doing business. In terms of the development of integration aspects in TM, technology identification again dominates, this time followed by technology commercialization. The least developed phase in this context is technology implementation. This may imply some deficiency of TM, but surprisingly also lower integration needs of TM required in this phase, which always depend on a particular company, technology and its application context (Chart 3).

\section{Chart 3}

\section{Development of integrated Technology management processes - Cumulative number of professional articles}

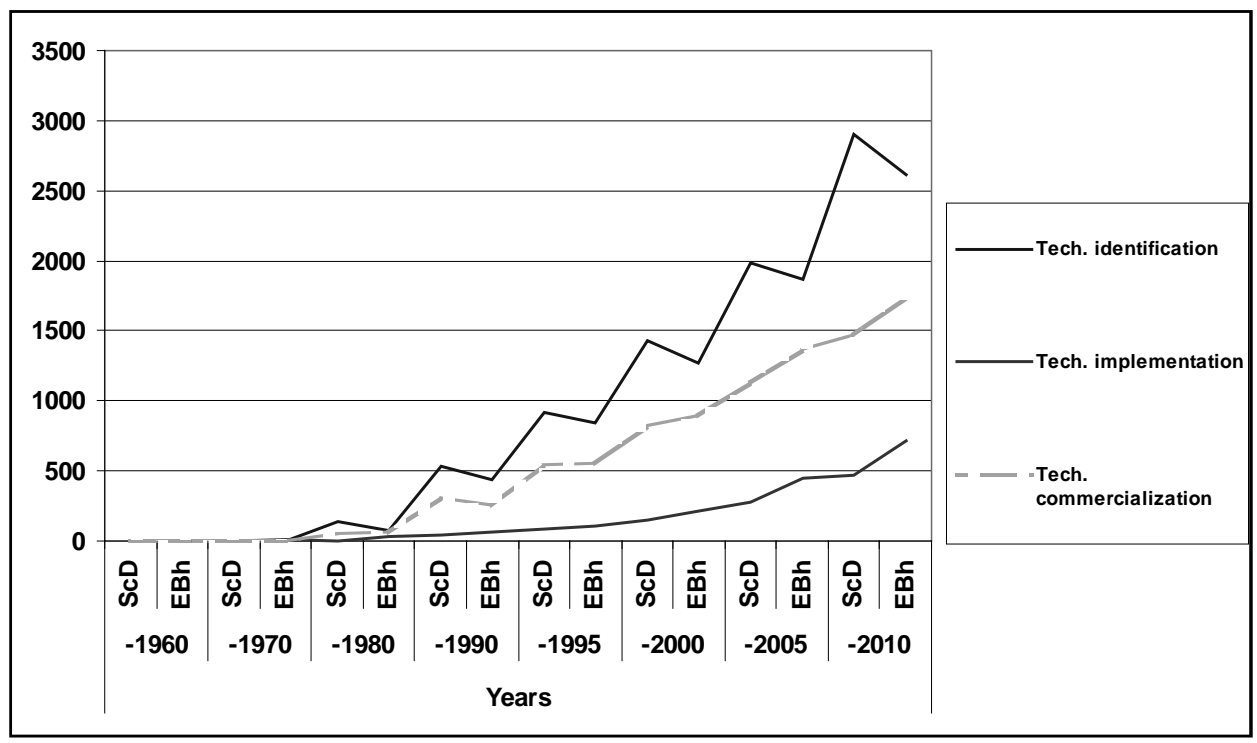

Source: Sciencedirect, 2011; EBSCOhost, 2011 


\section{References}

BALLARDINI, R. M. The Software Patent Thicket: A Matter Of Disclosure. SCRIPTed. 2009, vol. 6, no. 2. ISSN 1744-2567.

BARRELLA, E. M.; BUfFINTON, W. K. Business Assessment of Strategic Issues in Technology Management. Engineering Management Journal. 2009, vol. 21, no. 1, pp. 27-33. ISSN 0149-2063.

BELLAMY, A.; BECKER, P.; KUWIK, P. Developing a Technology Management curriculum from the perspective of strategic intent. The Journal of Technology Studies. 2001, vol. 29, no. 2, pp. 104-109. ISSN 1071-6084.

CCR. INVISTA Utilizes Honeywell's Diverse Technology Portfolio. China Chemical Reporter. 2007, vol. 18, no. 11, p. 15. ISSN 1002-1450.

CEGARRA-NAVARRO, J. H.; CEPEDA-CARRION, G.; JIMENEZ-JIMENEZ, D. Linking Unlearning with Innovation through Organizational Memory and Technology. Electronic Journal of Knowledge Management. 2010, vol. 8, no. 1, pp. 1-10. ISSN 1479-4411.

CHANG, H. F.; TZENG, G. H. A Causal Decision Making Model for Knowledge Management Capabilities to Innovation Performance in Taiwan's High-Tech Industry. Journal of Technology Management \& Innovation. 2010, vol. 5, no. 4, pp.137-146. ISSN 0718-2724.

CHEN, Y.; KANG, S. Integrating Technology Innovation Modes within Supply Chain Based Enterprise. Chongqing Technology and Business University [on-line]. March 2011. www.seiofbluemountain. com/upload/product/200910/2007glhy09a2.pdf.

COLLER IP. About Us. Coller IP [on-line]. July 2011. www.colleripmanagement.com/about/about.html.

DEHMAS, D. A.; KHERBA, N.; HACENE, F. B.; MERZOUK, N. K.; MERZOUK, M.; MAHMOUDI, H.; GOOSEN, M. F. A. On the use of wind energy to power reverse osmosis desalination plant: A case study from Ténès (Algeria). Renewable and Sustainable Energy Reviews. 2011, vol. 15, no. 2, pp. 956-963, ISSN 1364-0321.

DEMOPOULOS, A. STD industrial robots for advanced manufacturing and aerospace applications. Presentation of Absolute Robotics Ltd., 2009 [on-line]. March 2010. www.mec.cf.ac.uk/.../ExecutiveSummary_Absolute\%20Robotics\%20concept_18_09_09.ppt.

DICKINSON, M. W.; THORNTON, A. C.; GRAVES, S. Technology portfolio management: optimizing interdependent projects over multiple time periods. IEEE Transactions on Engineering Management. 2001, vol. 48, no. 4, pp. 518-527. ISSN 0018-9391.

EBSCOhost. Research database, EBSCOhost, 2011 [on-line]. June-August 2011. http://web.ebscohost.com/ehost/search/advanced?sid=96f6d24c-1aa3-4979-b5f1-c03994c54678\%40sessionmgr104\&vid=2\&hid $=113$.

EPRI. Full technology portfolio can reduce cost of CO2. Sustainable Facility. 2007, vol. 32, no. 10, p. 13. ISSN 1934-6980.

FOSFURI, A. The licensing dilemma: understanding the determinants of the rate of technology licensing. Strategic Management Journal. 2006, vol. 27, no. 12, pp. 1141-1158. ISSN 0143-2095.

GARTNER. Magic Quadrant for IT Project and Portfolio Management. Gartner, 2005 [on-line]. August 2011. www.techrepublic.com/whitepapers/magic-quadrant-for-it-project-and-portfolio-management-2005/143464.

GUNASEKARAN, A.; NGAI, E. W. T. Information systems in supply chain integration and management. European Journal of Operational Research. 2004, vol. 159, no. 2, pp. 269-295. ISSN 0377-2217.

HEIER. World's no. 1 brand, Heier, 2011 [on-line]. May 2011. www.haier.com.my/haiers-group.

IANSITI, M. Technology Integration: Making Critical Choices in a Dynamic World. Boston, Mass. : Harvard Business School Press, 1997. ISBN 087-5847-870.

IBM. IBM Interactive, IBM, 2010 [on-line]. March 2010. http://money.cnn.com/magazines/fortune/fortune500/2009/index.html.

IBM. IBM Report to Shareholders, IBM, 2010 [on-line]. March 2011.www.ibm.com/ibm/sjp/04_27_2010. html.

JEMALA, L'. Podnikatel'ský manažment a marketing. Bratislava : STU, 2008. ISBN 8022728607. 
JEMALA, M. Manažment technologických systémov - Identifikácia a prípadové štúdie. Bratislava : Vydavatel'stvo STU, 2011.

JEMALA, M. Evolution of Foresight in the Global Historical Context. Foresight. 2011, vol. 12, no. 4, pp. 65-81. ISSN 1463-6689.

JEMALA, M.; SVATÝ, F. Ontológia foresightu. Podnety pre tvorbu vízie SR na báze metodiky foresightu. Bratislava : Ekonóm, 2010. ISBN 978-80-225-2879-5.

JOHNSON, R. Developing oversight approaches to nanobiotechnology: the lessons of history. Journal of Law, Medicine \& Ethics. 2009, vol. 37, no. 4, pp. 587-593. ISSN 1748-720X.

KAMATH, V.; RODRIGUES, L. L. R.; DESAI, P. The Role Of Top Management in Using Knowledge Management as a Tool for Innovation - A System Dynamics Perspective. Proceedings of The World Congress on Engineering 2011, July 6-8, 2011, London, U.K., pp. 759-762.

KANTER, J. Boeing and Vestas form research partnership. The New York Times. 2009, 11th March. ISSN 0362-4331.

KOROL, A. G. Soviet education for science and technology. Cambridge : Technology Press of Massachusetts Institute of Technology, 1957. ISBN 083716978X.

LEONARDI, M. P. Indeterminacy and the discourse of inevitability in International technology management. Academy of Management Review. 2008, vol. 33, no. 4, pp. 975-984. ISSN 0363-7425.

LICHTENTHALER, U. Outbound open innovation and its effect on firm performance: Examining environmental influences. $R \& D$ Management. 2009, vol. 39, no. 4, pp. 317-330. ISSN 0033-6807.

MADHANI, P. M. Value Creation Through Cross-Functional Collaboration: Making a Case for SCM and Marketing Integration. Dharohar International Management Journal. 2011, vol. 1, no. 1, pp. 36-48. ISSN 2230-9357.

OMITI, O. J. F. Intellectual Asset Management for Sustainable Research. Proceedings of Sustainable Research and Innovation Conference., vol. 3, 5-6 May 2011, Jomo Kenyatta University of Agriculture and Technology, Nairobi, Kenya.

OZAKI, I., Keizai hatten no kozo bunseki I: The structure of economic development. Mita journal of economics. 1979, vol. 72, no. 6, pp. 84-112. ISSN 0026-6760.

PESLAK, A. A study of information technology integration. Journal of information systems applied research. 2011, vol. 4, no. 2, pp. 19-27. ISSN 1946-1836.

SCIENCEDIRECT. Research Database, Sciencedirect, 2011 [on-line]. June-August 2011. www. sciencedirect.com/science?_ob=MiamiSearchURL\&_method =requestForm\&_btn=Y\&_zone $=$ TopNavBar\&_origin $=$ bröwse\&_acct $=$ C $000051056 \&$ _version $=1$ \&_urlVersion $=1$ \&_use$\mathrm{rid}=1052399 \& \mathrm{md} \overline{5}=107 \mathrm{~b} 8 \mathrm{dcb} 923 \mathrm{~b} 70 \mathrm{ac} 4 \mathrm{addc} 8047361575 \overline{4}$.

SLATER, D. Intellectual Property Protection: The Fundamentals. CSO Data protection, 2010 [on-line]. March 2010. www.csoonline.com/article/204600/Intellectual_Property_Protection_The_Fundamental.

STEINER, G. A. Improving the transfer of government-sponsored technology. Business Horizons. 1966, vol. 9, no. 3, p. 55. ISSN 0007-6813.

SVATÝ, F.; JEMALA, M. Inovačná aktivita technológií a jej hodnotenie v prostredí znalostnej ekonomiky. Bratislava : Ekonóm, 2006. ISBN 80-225-2198-1.

SVATÝ, F.; JEMALA, M. Manažment technologických systémov. Bratislava : Ekonóm, 2009. ISBN 97880-225-2833-7.

TRAINOR, K. J.; RAPP, A.; BEITELSPACHER, L. S.; SCHILLEWAERT, N. Integrating information technology and marketing: an examination of the drivers and outcomes of e-marketing capability. Industrial marketing management. 2011, vol. 40, no. 1, pp. 162-174. ISSN 0019-8501. 


\title{
INTEGRATION OF TECHNOLOGY MANAGEMENT AND ITS DEVELOPMENT: TECHNOLOGY IMPLEMENTATION AND COMMERCIALIZATION
}

\begin{abstract}
Integrating technology and business strategy, technology capacities with customers' needs, technology and business processes require a three-step mechanism of technology management (TM), namely integration of technology identification, implementation, and potential technology commercialization processes. TM requires creation of a functional technology network and good communication channels between strategic and technology managers, technologists and workers, and between a company and its stakeholders. This partly methodological and partly analytical study focuses on identifying the links within and between technology implementation and commercialization processes that could ensure maximum synergies and benefits for TM. Its added value also lies in the bibliometric statistics of the ScienceDirect and EBSCOhost databases (1960-2010), done for the identification of trends in TM. According to the statistics, and in terms of the development of integration aspects in TM, technology identification dominates, followed by technology commercialization, while the technology implementation phase is the least developed.
\end{abstract}

Keywords: Integrated technology management, technology synergies, technology implementation, technology commercialization

JEL Classification: M11, O31, O32 